\title{
Experience as a Determinant of Declarative and Procedural Knowledge in School Football
}

\author{
Juan M. García-Ceberino ${ }^{1,2, * \mathbb{C} \text {, María G. Gamero }}{ }^{1,2}$, Sebastián Feu ${ }^{1,2}$ ) and \\ Sergio J. Ibáñez ${ }^{1,3}$ (D) \\ 1 Optimization of Training and Sports Performance Research Group (GOERD), University of Extremadura, \\ 10003 Cáceres, Spain; mgamerob@alumnos.unex.es (M.G.G.); sfeu@unex.es (S.F.); sibanez@unex.es (S.J.I.) \\ 2 Faculty of Education, University of Extremadura, 06006 Badajoz, Spain \\ 3 Faculty of Sports Science, University of Extremadura, 10003 Cáceres, Spain \\ * Correspondence: jgarciaxp@alumnos.unex.es; Tel.: +34-627-218-855
}

Received: 14 January 2020; Accepted: 6 February 2020; Published: 7 February 2020

\begin{abstract}
The study of declarative and procedural knowledge makes it possible to ascertain what cognitive processes are like during motor learning. This study aimed to compare, according to the methodology, gender and experience (football practise), and the levels of declarative and procedural knowledge after the implementation of two intervention programmes on school football including one based on the tactics learning and the other on the technique learning. A total of 41 students in the 5th year of primary education from a state school from Spain, distributed in two class groups, participated in the study. Each class group participated in a different intervention programme. The sample of subjects was equal (tactical programme $(n=20)$ and technical programme $(n=21))$. A panel of 13 experts validated both programmes. Levels of knowledge were measured using the Tactical Knowledge Assessment test in football. A descriptive analysis was performed to characterise the sample. Moreover, a t-test for independent samples, a t-test for related samples, and a $2 \times 2$ ANOVA (analysis of variance) were performed to compare the levels of knowledge between the pre-test and the post-test, according to the methodology, gender, and experience of the students. Results indicate that both intervention programmes induced higher levels of declarative and procedural knowledge in the post-test. Similarly, there were no significant differences with regard to the applied methodology. This fact is due to the heterogeneous character of the class groups with gender and experience showing effects on the levels of knowledge. The boys possessed greater experience and a higher level of knowledge compared to the girls.
\end{abstract}

Keywords: tactical games approach; direct instruction; gender; experience; physical education

\section{Introduction}

The teaching of invasion sports in primary education should be oriented toward educational objectives. Within this wide group of sports, football is the collaboration-opposition sport, which is most commonly taught in the school context in Spain [1]. Thus, the importance that football demands socially and at school leads to analysing the teaching-learning processes involved [2].

The physical education teaching approach must be in learning and, therefore, how sports are taught in physical education is as important as its content [3]. The teaching of invasion sports has traditionally focused on the technical element, leaving the tactical element to one side [4]. This implies the existence of deficits in the teaching-learning process regarding cognitive structures [5]. Following this line of thought, several studies have analysed the Student-Centered Approaches (SCAs) or tactics and the Teacher-Centered Approaches (TCAs) or technique, with the idea of contrasting which teaching methodologies induce higher levels of technical-tactical knowledge with significant differences 
being observed in the variables related to understanding the game like declarative knowledge or decision-making in favour of the SCAs [6,7]. Within the SCAs, the Tactical Games Approach (TGA) method stands out, and, within the TCAs, the Direct Instruction (DI) method is the most common [8].

The TGA method gives students the opportunity to learn through the real game. The teacher generates the learning through questions and interrogative feedback while encouraging decision-making. On the other hand, in the DI method, the students participate in technical components or drills. The teacher gives direct information to the students including prescriptive feedback, and they execute according to the guidelines given $[9,10]$. The TGA method is more successful than the DI method because it bases its learning on small-sided games. The students play with modified rules, fewer students, in tight spaces, etc., which improves tactical understanding when making decisions [11]. The DI method causes little learning progression because the students participate in isolated and descontextualized tasks of the real game [12]. For all these reasons, the TGA method is more appropriate for teaching invasion sports in physical education classes.

In the school context, several studies compare methodologies in different aspects like learning [7,13], and external and internal load [14], after the implementation of two different intervention programmes for basketball, with one based on a traditional methodology (Direct Instruction in Basketball) and another on an alternative methodology (Tactical Game in Basketball). There is also another study on teaching methodologies after the implementation of intervention programmes for football [15].

MacPhail et al. [11] highlight the importance of teaching technical-tactical aspects in invasion sports from the SCAs, based on integrating and total teaching, rather than TCAs, centered on teaching technical skills. Perceptive and cognitive factors take on greater importance in SCAs given their influence on decision-making and the transfer of learning [16]. Light et al. [17] point out that SCAs improve the ability to game, increase students' motivation, and provide positive affective learning experiences. Similarly, the teachers are the ones in charge of designing play tasks, which help the learners to develop knowledge and give them the opportunity to acquire interrelated technical-tactical aspects [18].

The students make decisions during sports practice thanks to the structures of prior knowledge that they possess and their ability to process new information $[19,20]$. In the same way, the students possess a great capacity to acquire knowledge at an early age [18]. Moreno et al. [21] indicate two types of knowledge: declarative and procedural. On the one hand, declarative knowledge refers to theoretical information that includes both technical-tactical aspects and rules. On the other hand, procedural knowledge refers to (tactical) decisions made in concrete game situations. Chatzipanteli et al. [9] indicate that students must have adequate declarative knowledge to improve procedural knowledge. Declarative knowledge must be conducted prior to problem solving and decision-making.

The level of the students' knowledge and their ability to make decisions are fundamental factors for effective sports practice [22]. Tactical knowledge will favour the development of decision-making skills during sports practice [23]. Similarly, an adequate base of prior knowledge together with different factors such as experience or formal instruction will help the students make game decisions in a more efficient manner [24]. Williams et al. [25] and García et al. [26] indicate that declarative and procedural knowledge are acquired through sports practice, differentiating the expert students from the novices in the structured memory, which they acquire with the practice of sport and the specific knowledge that they possess. For this reason, different studies conclude that the levels of knowledge and the experience of the students are intimately linked with students with more experience presenting higher levels of knowledge [27-29].

Regarding gender, both in the context of sports training and of the school, boys are associated with sports that involve physical contact, strength, and aggressiveness: football, basketball, handball, etc. On the other hand, girls are associated with sports related to rhythm and beauty such as gymnastics, figure skating, dance, etc. [30,31]. In spite of studying gender with respect to different variables, especially psychological ones [32,33], the research on differences in sports learning according to gender are scarce [34]. 
In general terms, experience (sport practice) and gender are two mediating variables that can explain the differences in the levels of declarative and procedural knowledge recorded in physical education classes regardless of the teaching method applied by the teacher. In the Serra-Olivares [34] study, boys recorded higher levels of declarative and procedural knowledge than girls. In addition, the students with the most experience also recorded better results. This same author indicates that more studies are needed to analyze the relationships between experience, knowledge, skill, and gender in school sports.

The scientific literature includes research on the declarative and procedural knowledge of young students, after being taught football, in the school context [34-36] and in the context of sports training [18,25,37]. Research on football tends to study elite players [38]. In addition, many interviews, videos, questionnaires, and written tests are used as tools to evaluate the knowledge of learners in football [39].

Studying declarative and procedural knowledge makes it possible to ascertain students' cognitive processes [2]. This knowledge is of great importance in the teaching-learning process of an invasion sport such as football [39]. The literature does not include studies, which, as well as analysing declarative and procedural knowledge, take into account the gender and level of experience of the students. The teaching of football in the Spanish educational system is common since it is necessary to study the influence exerted by the experience of the out-of-school activity in the school context. Thus, the purpose of this study was to compare, according to the teaching method, gender and experience (football practise), the declarative and procedural knowledge acquired by two groups of students from the 5th year of a state school in Spain after the implementation of two intervention programmes on school football. Each intervention programme was based on a different method, TGA and DI, and each programme was applied in a different class group.

\section{Materials and Methods}

\subsection{Design}

A quasi-experimental longitudinal design was used with a pre-test and a post-test [40] to determine if there were differences in the level of declarative and procedural knowledge after the implementation of two intervention programmes on school football.

\subsection{Sample}

A total of 41 students, aged 10 or 11 years (Age: $10.63 \pm 0.488$ years), from the 5th year of primary education from a state school in the west-central region of Spain, participated in the study. They were divided into two class groups depending on the intervention programme applied. The distribution by gender in each class in the Spanish state system is mixed and heterogeneous, and it is organized by the school's academic authorities. The implementation of the programmes to the groups was random. The students from the 5th year group A participated in the Tactical Games Approach Soccer (TGAS), and the students from the 5th year group B in the Direct Instruction Soccer (DIS) intervention programme. To be able to take part in the study, it was necessary for the parents or legal guardians to sign their informed consent. Moreover, this study was included in the school's curricular project.

The students had no previous contact with the invasion sport of football in their physical education classes, although $15 \%$ of the students who participated in the TGAS intervention programme and $42.9 \%$ of those who participated in the DIS intervention programme practised football as an out-of-school activity (or as sports training) 4 hours per week, which was divided into 3 hours training and a one-hour official match. All these students were boys. None of the girls from either group practised football as an out-of-school activity. Moreover, $40 \%$ of the students who participated in the TGAS programme and $71.43 \%$ of the students who participated in the DIS programme were boys.

This heterogeneous character of the class groups regarding level of practise and gender was conditioned by the random distribution of the students, according to the Spanish educational system, 
which does not segregate students according to gender. The groups were not modified to maintain the ecological validity of the study.

The characteristics of the students participating in the study are shown in Table 1.

Table 1. Characteristics of the students participating in the study.

\begin{tabular}{|c|c|c|c|c|c|c|c|c|}
\hline \multirow{3}{*}{ Methodology and Class Group } & \multicolumn{4}{|c|}{ Gender } & \multicolumn{4}{|c|}{ Experience (Football Practice) } \\
\hline & \multicolumn{2}{|c|}{ Boy } & \multicolumn{2}{|c|}{ Girl } & \multicolumn{2}{|c|}{ Yes } & \multicolumn{2}{|c|}{ No } \\
\hline & $n$ & $\%$ & $n$ & $\%$ & $n$ & $\%$ & $n$ & $\%$ \\
\hline TGAS (5 A) & 8 & 40.00 & 12 & 60.00 & 3 & 15.00 & 17 & 85.00 \\
\hline DIS (5 B) & 15 & 71.43 & 6 & 28.57 & 9 & 42.90 & 12 & 57.10 \\
\hline
\end{tabular}

Note: TGAS: Tactical Games Approach Soccer. DIS: Direct Instruction Soccer.

\subsection{Variables}

Three independent variables were determined: i) the TGAS (based on the TGA method) and the DIS (based on the DI method) intervention programmes were designed in a similar manner, but were based on different methodologies. Both intervention programmes were similar $(p>0.05)$ with a high degree of association in different variables, in terms of: the number of tasks, the number of sessions, the phases of play, the specific contents, and the didactic objectives. Differences were identified in the rest of the studied variables due to the particularities of each teaching methodology, i.e., game situation, teaching means, level of opposition, degree of opposition, density of the task, competitive load, and cognitive implication $(p<0.05)$ [41]. The TGAS and DIS programmes were validated by a panel of 13 judicial experts (Aiken's $V \geq 0.69, \alpha=0.97$ ). To be considered as an expert judge, they had to meet a series of criteria: having a Doctoral degree, being a Higher Education faculty member in the area of sport pedagogy and/or invasion sports, possessing the highest federative certification level (level III) in invasion sports, having 10 years of experience or more as an invasion sports coach, or having authored publications on sport pedagogy and/or teaching methods [42], ii) the gender of the students, and iii) the practice of football as an out-of-school activity, that is the experience of the students in football.

The TGAS and DIS programmes present optimal levels of validity and reliability. Thus, both are considered valid and reliable for the teaching of football in the school context as well as for analysing the level of learning attained by the students after their implementation [42].

The dependent variable for the study was the levels of declarative and procedural knowledge [21] acquired by the students after the implementation of the intervention programmes. Both types of knowledge are related to the attack phase in football.

\subsection{Instruments}

The declarative and procedural knowledge of the studied students was analysed using the Tactical Knowledge Assessment test in Football (TCTOF by its Spanish acronym). This instrument is a written multiple-choice test divided into two parts. The first part is in written form and evaluates declarative knowledge ("to know what, and why to do it") and the second part written with representative figures of a game situation to evaluate procedural knowledge ("to know how and when to do it") [39]. The TCTOF is linked to the action principles of invasion sports [43].

Table 2 shows the indicators evaluated by the TCTOF for declarative and procedural knowledge [39].

Using consensual agreement [44], it was decided to eliminate nine of the 36 items aimed at evaluating declarative knowledge and one of the 16 items aimed at evaluating procedural knowledge since they presented greater complexity with regard to the educational stage of the participating students. 
Lastly, the data collected using the TCTOF were exported to the SPSS 21.0 statistical program (IBM Corp. Released 2012. IBM SPSS Statistics for Windows, Version 21., IBM Corp, Armonk, NY, USA) for their later descriptive and inferential analysis.

Table 2. Indicators evaluated by the TCTOF.

\begin{tabular}{ll}
\hline \multicolumn{1}{c}{ Declarative Knowledge } \\
\hline - & Individual technical-tactical elements in football, related to action principles for attack. \\
- & Individual technical-tactical elements in football, not related to action principles for attack. \\
- & Action principles for attack in invasion games and sports. \\
\hline & \multicolumn{1}{c}{ Procedural Knowledge } \\
\hline - & Individual technical-tactical elements in situations of maintaining possession of the ball in football. \\
- Individual technical-tactical elements in situations of advancing towards the opponent's goal in football. \\
\hline
\end{tabular}

Note: TCTOF: Tactical Knowledge Assessment test in football.

\subsection{Procedure}

First, despite the fact that the study did not require invasive measures to obtain the data, the University Bioethics Committee was asked for its approval (Ref. 09/2018). Then authorisation was requested from the school and the physical education teachers. Once authorisation was obtained, the parents or legal guardians of the students were asked for their informed consent by signing a document that was in accordance with the ethical guidelines of the Declaration of Helsinki and Organic Law 15/1999 of 13th December on the Protection of Personal Information (LOPD) (BOE 14 December 1999). Similarly, the study was approved by the school council within the school curriculum.

After obtaining the necessary authorisations, an initial evaluation was conducted, including the pre-test, in which the students completed the TCTOF. This evaluation also included for the study purposes the following information: i) the school year (5A or 5B), ii) age in years, iii) years of football practice $(1,2,3,4$, or more than 5), and iv) football practice in the out-of-school context (Yes or No).

After that, the TGAS and DIS programmes were implemented, with one to each class group for 11 sessions, including sessions of the $3 \times 3$ games of the pre-test and post-test. The teaching progressed based on the difficulty of the tasks. The teacher's communications were also adapted to the type of feedback characteristic for each methodology [41].

Lastly, after the application of the intervention programmes, there was a final evaluation, which is the post-test, when the students again completed the TCTOF.

The pre-test and post-test assessments lasted 55 minutes each, and each time, the principal investigator explained the TCTOF, so that it was completely clear how it had to be filled out.

Figure 1, which was designed by García-Ceberino et al. [15], summarizes the structure of the TGAS and DIS intervention programmes. 


\begin{tabular}{|c|c|c|}
\hline Intervention programme & $\begin{array}{c}\text { Interrogative (students answer } \\
\text { questions and make decisions) }\end{array}$ \\
\hline Seduced games, with opponents and \\
modified rules (decision making)
\end{tabular}

Figure 1. Structure of the TGAS and DIS intervention programmes. Note: TGAS: Tactical Games Approach Soccer. DIS: Direct Instruction Soccer.

\subsection{Statistical Analyses}

Firstly, the tests of assumption of criteria were conducted to identify the characteristics of the study data [45]. The Shapiro-Wilks and Levene tests showed that the study variables fulfilled the assumption of normality, so that mathematical parametric models could be used to test the hypothesis.

A descriptive analysis was then performed to ascertain the participants' characteristics according to gender and experience in football. Then, a t-test for independent samples was performed to compare the level of declarative and procedural knowledge between both class groups (pre-test). Similarly, a t-test for independent samples was conducted to contrast the level of declarative and procedural knowledge resulting from the implementation of both intervention programmes (post-test) [45].

A t-test for related samples was also performed to contrast the level of declarative and procedural knowledge acquired by the students in each class group after the implementation of the intervention programmes (post-test) with respect to their initial level (pre-test) [45].

Lastly, to determine the effect that gender and experience in football had in the study in both methodologies on the level of declarative and procedural knowledge acquired by the students after the implementation of the intervention programmes (post-test), a $2 \times 2$ ANOVA for repeated measures was performed [45], using gender and experience as co-variables.

Figure 2 presents the statistical tests used to compare the declarative and procedural knowledge in the pre-test and post-test, according to the methodology, gender, and football experience. 


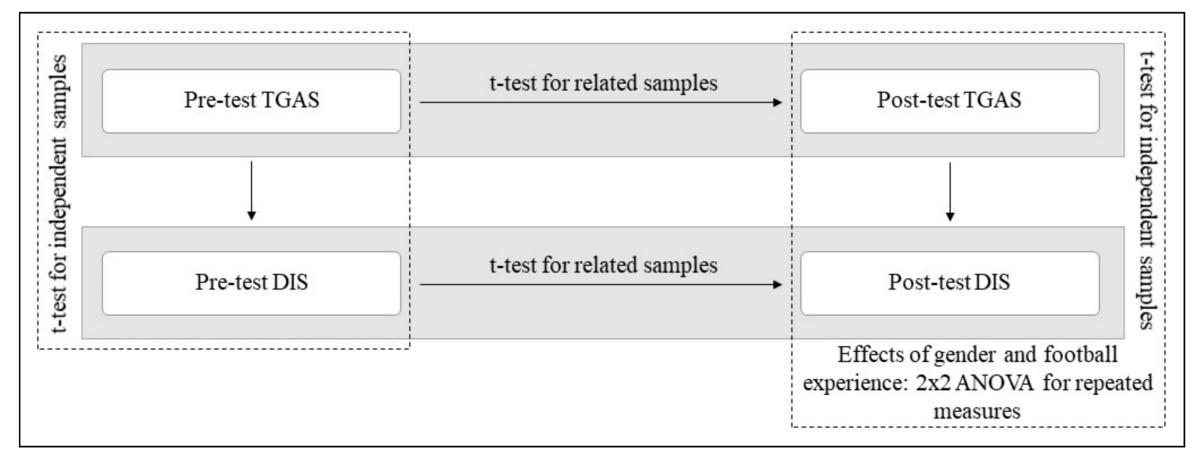

Figure 2. Statistical tests used to compare the declarative and procedural knowledge in the pre-test and post-test. Note: TGAS: Tactical Games Approach Soccer. DIS: Direct Instruction Soccer.

The effect size of the statistical analyses was determined using Cohen's $d\left(\mathrm{~d}_{\text {cohen }}\right)$ and partial eta squared ( 2$)[46,47]$.

\section{Results}

The descriptive results for each intervention programme according to gender and experience in football are presented in Table 3. The boys who participated in each programme presented higher levels of declarative and procedural knowledge in the pre-test and post-test compared to the girls. Similarly, the students from both groups who practised football as an out-of-school activity presented higher levels of declarative and procedural knowledge in the pre-test and post-test.

Table 3. Descriptive results of the pre-test and post-test according to gender and football experience.

\begin{tabular}{|c|c|c|c|c|c|}
\hline Programme & Knowledge & Gender & Pre-test $M \pm S D$ & Post-test $\mathrm{M} \pm \mathrm{SD}$ & Pre-Post \\
\hline \multirow[t]{9}{*}{ TGAS (5 A) } & \multirow{2}{*}{ Declarative } & Boy & $45.83 \pm 9.69$ & $52.31 \pm 16.01$ & -6.48 \\
\hline & & Girl & $36.11 \pm 9.75$ & $41.05 \pm 14.08$ & -4.94 \\
\hline & \multirow{2}{*}{ Procedural } & Boy & $34.17 \pm 16.11$ & $44.17 \pm 15.91$ & -10.00 \\
\hline & & Girl & $30.00 \pm 14.35$ & $28.33 \pm 8.59$ & 1.67 \\
\hline & Knowledge & Experience & Pre-test $M \pm S D$ & Post-test $\mathrm{M} \pm \mathrm{SD}$ & Pre-Post \\
\hline & \multirow{2}{*}{ Declarative } & Yes & $49.38 \pm 2.14$ & $65.43 \pm 5.66$ & -16.05 \\
\hline & & No & $38.34 \pm 10.71$ & $42.05 \pm 13.98$ & -3.71 \\
\hline & \multirow{2}{*}{ Procedural } & Yes & $48.89 \pm 16.78$ & $60.00 \pm 6.67$ & -11.11 \\
\hline & & No & $28.63 \pm 12.64$ & $30.20 \pm 9.46$ & -1.57 \\
\hline Programme & Knowledge & Gender & Pre-test $M \pm S D$ & Post-test $\mathrm{M} \pm \mathrm{SD}$ & Pre-Post \\
\hline \multirow[t]{9}{*}{ DIS (5 B) } & \multirow{2}{*}{ Declarative } & Boy & $51.11 \pm 9.10$ & $57.04 \pm 14.47$ & -5.93 \\
\hline & & Girl & $37.04 \pm 17.37$ & $43.21 \pm 14.57$ & -6.17 \\
\hline & \multirow{2}{*}{ Procedural } & Boy & $39.55 \pm 10.83$ & $48.89 \pm 21.48$ & -9.34 \\
\hline & & Girl & $22.22 \pm 8.07$ & $24.44 \pm 9.11$ & -2.22 \\
\hline & Knowledge & Experience & Pre-test $M \pm S D$ & Post-test $\mathrm{M} \pm \mathrm{SD}$ & Pre-Post \\
\hline & \multirow{2}{*}{ Declarative } & Yes & $50.62 \pm 8.69$ & $57.20 \pm 16.57$ & -6.58 \\
\hline & & No & $44.44 \pm 15.71$ & $50.00 \pm 14.60$ & -5.56 \\
\hline & \multirow{2}{*}{ Procedural } & Yes & $42.96 \pm 11.60$ & $56.30 \pm 23.12$ & -13.34 \\
\hline & & No & $28.33 \pm 9.90$ & $31.11 \pm 13.13$ & -2.78 \\
\hline
\end{tabular}

Note: M: Mean. SD: Standard Deviation. TGAS: Tactical Games Approach Soccer. DIS: Direct Instruction Soccer.

Table 4 compares the level of declarative and procedural knowledge between both class groups in the pre-test and post-test. It shows that the students who participated in the DIS programme presented higher levels of initial declarative and procedural knowledge (pre-test) than the students who participated in the TGAS programme. However, these differences were not statistically significant $(p>0.05)$ with an intermediate effect size $(0.500-0.799)$ in the level of declarative knowledge and 
small (0.200-0.499) in the level of procedural knowledge. After the implementation of the intervention programmes (post-test), the students who participated in the DIS programme continued to show higher levels of declarative and procedural knowledge than the students who participated in the TGAS programme. However, the differences were not statistically significant $(p>0.05)$ and showed a small effect size (0.200-0.499).

Table 4. Level of declarative and procedural knowledge between both class groups in the pre-test and post-test.

\begin{tabular}{|c|c|c|c|c|c|c|c|c|}
\hline Test & Knowledge & Programme & $n$ & $\mathrm{M} \pm \mathrm{SD}$ & $t$ & $d f$ & $p$ & $d_{\text {cohen }}$ \\
\hline \multirow{4}{*}{ Pre-test } & \multirow{2}{*}{ Declarative } & DIS & 21 & $47.09 \pm 13.26$ & \multirow{2}{*}{1.882} & \multirow{2}{*}{39} & \multirow{2}{*}{0.067} & \multirow{2}{*}{0.588} \\
\hline & & TGAS & 20 & $40.00 \pm 10.65$ & & & & \\
\hline & \multirow{2}{*}{ Procedural } & DIS & 21 & $34.60 \pm 12.76$ & \multirow{2}{*}{0.681} & \multirow{2}{*}{39} & \multirow{2}{*}{0.500} & \multirow{2}{*}{0.213} \\
\hline & & TGAS & 20 & $31.67 \pm 14.81$ & & & & \\
\hline Test & Knowledge & Programme & $n$ & $M \pm S D$ & $t$ & $d f$ & $p$ & $d_{\text {cohen }}$ \\
\hline \multirow{4}{*}{ Post-test } & \multirow{2}{*}{ Declarative } & DIS & 21 & $53.09 \pm 15.51$ & \multirow{2}{*}{1.553} & \multirow{2}{*}{39} & \multirow{2}{*}{0.129} & \multirow{2}{*}{0.485} \\
\hline & & TGAS & 20 & $45.55 \pm 15.53$ & & & & \\
\hline & \multirow{2}{*}{ Procedural } & DIS & 21 & $41.90 \pm 21.72$ & \multirow{2}{*}{1.258} & \multirow{2}{*}{39} & \multirow{2}{*}{0.216} & \multirow{2}{*}{0.393} \\
\hline & & TGAS & 20 & $34.67 \pm 14.12$ & & & & \\
\hline
\end{tabular}

Note: M: Mean. SD: Standard Deviation. $d f$ : degrees of freedom. TGAS: Tactical Games Approach Soccer. DIS: Direct Instruction Soccer. * $p<0.05$.

The level of declarative and procedural knowledge acquired by the students in each class group, after the implementation of the two intervention programmes (post-test), is shown in Table 5. It can be seen that both class groups present higher levels of declarative and procedural knowledge with regard to their initial level (pre-test). There were significant differences $(p<0.05)$ with a small effect size (0.200-0.499) in the level of declarative and procedural knowledge between the pre-test and post-test of the class group that participated in the DIS programme. However, there were no significant differences $(p>0.05)$ and with a small effect size $(0.200-0.499)$ in the level of declarative and procedural knowledge between the pre-test and the post-test of the class group that participated in the TGAS programme.

Table 5. Level of declarative and procedural knowledge acquired in each class group (pre-test/post-test).

\begin{tabular}{|c|c|c|c|c|c|c|c|}
\hline Programme & Knowledge & $n$ & $\mathbf{M} \pm \mathrm{SD}$ & $t$ & $d f$ & $p$ & $d_{\text {cohen }}$ \\
\hline \multirow{2}{*}{ DIS } & $\begin{array}{l}\text { Declarative pre-test } \\
\text { Declarative post-test }\end{array}$ & $\begin{array}{l}21 \\
21\end{array}$ & $\begin{array}{l}47.09 \pm 13.26 \\
53.09 \pm 15.51\end{array}$ & -2.274 & 20 & $0.034^{*}$ & 0.411 \\
\hline & $\begin{array}{l}\text { Procedural pre-test } \\
\text { Procedural post-test }\end{array}$ & $\begin{array}{l}21 \\
21\end{array}$ & $\begin{array}{l}34.60 \pm 12.76 \\
41.90 \pm 21.72\end{array}$ & -2.368 & 20 & $0.028 *$ & 0.339 \\
\hline \multirow{2}{*}{ TGAS } & $\begin{array}{l}\text { Declarative pre-test } \\
\text { Declarative post-test }\end{array}$ & $\begin{array}{l}20 \\
20\end{array}$ & $\begin{array}{l}40.00 \pm 10.65 \\
45.56 \pm 15.53\end{array}$ & -1.899 & 19 & 0.073 & 0.401 \\
\hline & $\begin{array}{l}\text { Procedural pre-test } \\
\text { Procedural post-test }\end{array}$ & $\begin{array}{l}20 \\
20\end{array}$ & $\begin{array}{l}31.67 \pm 14.81 \\
34.67 \pm 14.12\end{array}$ & -1.013 & 19 & 0.324 & 0.207 \\
\hline
\end{tabular}

Note: M: Mean. SD: Standard Deviation. $d f$ : degrees of freedom. TGAS: Tactical Games Approach Soccer. DIS: Direct Instruction Soccer. * $p<0.05$.

Table 6 presents the effect that gender and experience in football have in the two methodologies studied on the level of declarative and procedural knowledge acquired by the students. Regarding gender, it can be seen that there were no significant differences $(p>0.05)$ and, with a small effect size (0.010-0.059), in declarative knowledge and no effect (0.000-0.009) in procedural knowledge, according to the methodology used. However, there were significant differences $(p<0.05)$ with a large effect size $(\geq 0.140)$ in both types of knowledge, according to the gender, so that this variable affects 
the levels of declarative and procedural knowledge acquired by both class groups. Similarly, with respect to the students' experience in football, we can see that there were no significant differences either $(p>0.05)$ and, with a small effect size (0.010-0.059) in declarative knowledge and no effect (0.000-0.009) in procedural knowledge, according to the methodology used. However, there were significant differences $(p<0.05)$ and, with an intermediate effect (0.060-0.139), in declarative and a large effect $(\geq 0.140)$ in procedural knowledge in the experience variable, so that practising football in an out-of-school context also affects the levels of declarative and procedural knowledge acquired by both class groups.

Table 6. Effect of the methodologies on gender and experience in football.

\begin{tabular}{|c|c|c|c|c|c|c|c|}
\hline & Knowledge & Variable & $d f$ & Quadratic $M$ & $F$ & $p$ & $\eta 2$ \\
\hline \multirow{6}{*}{ Gender } & \multirow{3}{*}{ Declarative } & Intersection & 1 & 32236.844 & 131.589 & $0.000 *$ & 0.776 \\
\hline & & Gender & 1 & 2671.214 & 10.904 & $0.002 *$ & 0.223 \\
\hline & & Methodology & 1 & 225.811 & 0.922 & 0.343 & 0.024 \\
\hline & \multirow{3}{*}{ Procedural } & Intersection & 1 & 26126.118 & 77.448 & 0.000 * & 0.671 \\
\hline & & Gender & 1 & 4163.195 & 12.341 & 0.001 * & 0.245 \\
\hline & & Methodology & 1 & 2.010 & 0.006 & 0.939 & 0.006 \\
\hline \multirow{6}{*}{ Experience } & \multirow{3}{*}{ Declarative } & Intersection & 1 & 20135.160 & 73.660 & $0.000 *$ & 0.660 \\
\hline & & Experience & 1 & 1593.121 & 5.828 & $0.021 *$ & 0.133 \\
\hline & & Methodology & 1 & 371.978 & 1.361 & 0.251 & 0.035 \\
\hline & \multirow{3}{*}{ Procedural } & Intersection & 1 & 26091.556 & 101.178 & $0.000 *$ & 0.727 \\
\hline & & Experience & 1 & 7182.556 & 27.852 & $0.000 *$ & 0.423 \\
\hline & & Methodology & 1 & 16.116 & 0.062 & 0.804 & 0.002 \\
\hline
\end{tabular}

Note: M: Mean. $d f$ : degrees of freedom. ${ }^{*} p<0.05$.

\section{Discussion}

Currently, declarative and procedural knowledge are tools used to assess cognitive aspects in the evaluation of invasion sports like football [2]. This research has contributed to the study of levels of declarative and procedural knowledge resulting from the implementation of two intervention programmes, based on two different teaching methodologies, in two groups of students in primary education of a state school in Spain. The results indicate that the TGAS and DIS programmes induced improvements in the levels of declarative and procedural knowledge in both class groups. Moreover, the students who did not have knowledge of football improved and, those who did have knowledge, improved even more. The students' gender and experience (football practice) affected the levels of declarative and procedural knowledge in the pre-test and post-test. The students from both class groups had more difficulties with regard to procedural knowledge (behaviours or strategies to be used in different play situations).

Different studies carried out on invasion sports like football [6] or basketball [7] state that the SCAs or tactics induce higher levels of knowledge. In this research, the students who participated in the DIS programme, based on technique, showed significant differences in declarative and procedural knowledge between the pre-test and the post-test, while the students who participated in the TGA programme, based on tactics, did not present significant differences in declarative and procedural knowledge between the pre-test and post-test. This may be due to the effect of the students' gender and experience in the teaching of the invasion sport of football. In this respect, $40 \%$ of the students who participated in the TGAS programme were boys and 15\% practised football in an out-of-school context while $71.43 \%$ of the students who participated in the DIS programme were boys and $42.9 \%$ practised football in the out-of-school context. None of the girls had experience in football. The boys' percentage and experience in football was very low in the TGAS programme. Therefore, this programme did not present significant differences. Several studies have identified the fact that boys are more interested in practising football than girls both in the school playtime [48] and in an out-of-school context [49]. In this study, the students who had no knowledge of football improved equally independently of the 
method and, the students who did have knowledge, improved even more with the TGAS programme. The characteristics of the students who participated in the study show the heterogeneity of the groups, which may have affected the results. Different studies indicate that the multiplicity of behaviours and/or solutions that invasion sports offer within a class group with very dissimilar capacities and knowledge make the teaching task very difficult $[50,51]$. Spatial and reglementary adaptations are needed to facilitate the teaching and evaluation of football in the school context [52].

Other similar studies that compared the effects of implementing two intervention programmes for school basketball using different methodologies based on TGA (Tactical Game is Basketball) and DI (Direct Instruction in Basketball) found improvements with both intervention programmes, but the students who participated in the TGA programme reached a higher degree of learning $[7,13]$. Equally, in the analysis of the physical demands involved with the implementation of these programmes and their relation with the learning acquired by the students, it was found that the TGA methodology produced better results in the variables of an external and an internal load than the DI methodology, which permits a greater development of physical fitness in the students and better performance indicators in the game [14]. García-Ceberino et al. [15] also indicated that the TGA method favors the physical fitness of students. These results led to the recommendation that physical education teachers use a TGA method for teaching invasion sports in physical education classes [53].

Students have different levels of knowledge as a function of their experience in sports practice [27, 29]. Persky et al. [54] state that the main element that differentiates novice students from the experts is decision-making. The results obtained in this study indicate that the students with more experience reached a higher level of declarative and procedural knowledge. However, the students who participated in the TGAS intervention programme learned more. According to Serra-Olivares et al. [23], the level of specific knowledge of football and the experience of the students are intimately related. The results of this investigation coincide with several studies where the structures of technical-tactical knowledge and decision-making in football were analysed in the school context including in secondary education [36] and in primary education [34] as well as in the out-of-school context [18,55]. Experience determines the learning attained by the students since knowledge is acquired by practising the sport. The boys participating in the study tend to practise out-of-school football more often than the girls, which means that the former reached higher levels of knowledge in the pre-test and post-test.

The level of declarative knowledge acquired by both groups was higher than the level of procedural knowledge. This could be due to the fact that the teaching they have received in previous years has been more focused on technical aspects, without taking into account the strategies to be implemented during the game (tactical decisions) and the difficulties for interpreting the most suitable tactical decision in each play situation [37]. This study highlights the importance of making the right decision depending on the situation that is presented and, on this basis, choosing the technical-tactical element to be implemented. Similarly, the processes of learning and decision-making are influenced by the egocentrism that characterises students of these ages, which leaves the group aspects of the game [43]. The problem of the students to interpret the most suitable tactical decisions in every game situation that is considered can be due to the tendency of teachers to use TCAs for teaching invasion sports in physical education classes [56], which suppresses creativity and decision-making.

Lastly, the gender of the students also affected the level of declarative and procedural knowledge. Boys present higher levels of knowledge than girls. Serra-Olivares [34] identified that the gender variable was determinant in the levels of declarative and procedural knowledge of students of primary education. The boys showed significantly higher levels of knowledge than the girls. This is because they tend to practise football more often. This could be because boys tend to practise sports that involve physical contact, strength, and aggressiveness such as football, basketball, handball, etc. whereas girls tend to practise sports involving rhythm and beauty such as gymnastics, figure skating, dance, etc. [30,31]. Slingerland et al. [57] indicate that playing invasion games in school (football, handball, basketball, etc.) could be a strategy for the physical education teachers to foment the perceived competence of the girls and their physical activity in this type of game. 
Thus, the findings of this study could suggest that the differences in the levels of declarative and procedural knowledge of the students participating in the study are due to the effect of their gender and experience in football, which highlights the heterogeneous distribution of groups in physical education classes. The random distribution of the students, according to the Spanish educational system, conditions the heterogeneous distribution of the groups regarding the level of practice and gender. Further research is needed to delve more deeply into the study of cognitive structures of players at the sports initiation stage [27]. Following this line of thought, there are few studies that analyse declarative and procedural knowledge in the school context and, in particular, in primary education $[34,58]$.

The students were not grouped in homogeneous groups due to the legal organization of the class groups. However, this fact allowed us to learn about the influence of gender and previous experiences in the results. Likewise, new research studies including more participants are needed to improve and provide more information.

The Spanish educational system recommends using the technical and tactical contents common to invasion sports. The transfer between invasion sports with a similar internal logic can be studied through declarative and procedural knowledge. Students can transfer knowledge between different sports by providing common solutions to the same tactical problem. In this sense, the SCAs are more favorable for the transfer of knowledge [16,59]. This research missed studying whether the students who participated in both intervention programmes were able to transfer the acquired knowledge to other invasion sports with the same internal logic. The study of knowledge transfer between common sports is recommended for future research. In addition, it is necessary to study the influence of gender and experiences in learning other sports.

\section{Conclusions}

The results show that the TGAS and DIS intervention programmes induced improvement in the levels of declarative and procedural knowledge. However, there were no significant differences between the groups according to the teaching method used. The heterogeneous nature of the groups regarding gender and experience affected the levels of declarative and procedural knowledge after the application of the intervention programmes. The boys had greater experience and a higher level of knowledge. The students who had no knowledge of football improved equally independently of the method and, those who did have knowledge, improved even more with the TGAS intervention programme. Similarly, the level of declarative knowledge shown by both groups was higher than that of procedural knowledge, which shows knowledge is more centred on the technical aspects than on the behaviours and/or strategies that should be used (tactical decisions). Thus, further research is needed to study the methodologies for the teaching of invasion sports such as football at the primary education stage and their relation with students' cognitive structures.

Author Contributions: Conceptualization, J.M.G.-C., S.F., and S.J.I. Methodology, J.M.G.-C., S.F., and S.J.I. Formal analysis, J.M.G.-C. Reviewers, M.G.G., S.F., and S.J.I. Writing-original draft preparation, J.M.G.-C. Writing-review and editing, M.G.G., S.F., and S.J.I. Visualization, J.M.G.C. Supervision, M.G.G., S.F., and S.J.I. All authors have read and approved the manuscript.

Funding: This study has been partially subsidized by the Aid for Research Groups (GR18170) from the Regional Government of Extremadura (Department of Employment, Companies and Innovation), with a contribution from the European Union from the European Funds for Regional Development.

Acknowledgments: The authors thank the Rodeo school, the physical education teachers, and the students for participating in the research.

Conflicts of Interest: The authors declare no conflict of interest. 


\section{References}

1. González-Víllora, S.; Gutiérrez, D.; Pastor-Viñedo, J.C.; Fernández, J.G. Análisis funcional de los deportes de invasión: Importancia del subsistema técnico-táctico en el juego. Concreción en el fútbol. Retos Nuevas Tend. Educ. Física Deporte Recreación 2007, 12, 18-28.

2. Otero, F.M.; González, J.A.; Calvo, A. Validación de instrumentos para la medición del conocimiento declarativo y procedimental y la toma de decisiones en el fútbol escolar. Retos Nuevas Tend. Educ. Física Deporte Recreación 2012, 22, 65-69.

3. Stolz, S.A.; Pill, S. A narrative approach to exploring TGfU-GS. Sport Educ. Soc. 2016, 21, 239-261. [CrossRef]

4. Gray, S.; Sproule, J. Developing pupils' performance in team invasion games. Phys. Educ. Sport Pedagog. 2011, 16, 15-32. [CrossRef]

5. Griffin, L.L.; Butler, J.I. Teaching Games for Understanding; Human Kinetics: Champaign, IL, USA, 2005.

6. Blomqvist, M.; Vänttinen, T.; Luhtanen, P. Assessment of secondary school students' decision-making and game-play ability in soccer. Phys. Educ. Sport Pedagog. 2005, 10, 107-119. [CrossRef]

7. González-Espinosa, S.; Feu, S.; García-Rubio, J.; Antúnez, A.; García-Santos, D. Diferencias en el aprendizaje según el método de enseñanza-aprendizaje en el baloncesto. Rev. Psicol. Deporte 2017, 26, 65-70.

8. Metzler, M.W. Instructional Models for Physical Education, 3rd ed.; Holocomb Hathaway: Scottsdale, AZ, USA, 2011.

9. Chatzipanteli, A.; Digelidis, N.; Karatzoglidis, C.; Dean, R. A tactical-game approach and enhancement of metacognitive behaviour in elementary school students. Phys. Educ. Sport Pedagog. 2016, 21, 169-184. [CrossRef]

10. Smith, L.; Harvey, S.; Savory, L.; Fairclough, S.; Kozub, S.; Kerr, C. Physical activity levels and motivational responses of boys and girls: A comparison of direct instruction and tactical games models of games teaching in physical education. Eur. Phys. Educ. Rev. 2015, 21, 93-113. [CrossRef]

11. MacPhail, A.; Kirk, D.; Griffin, L. Throwing and catching as relational skills in game play: Situated learning in a modified game unit. J. Teach. Phys. Educ. 2008, 27, 100-115. [CrossRef]

12. Light, R.L.; Harvey, S.; Mouchet, A. Improving 'at-action' decision-making in team sports through a holistic coaching approach. Sport Educ. Soc. 2014, 19, 258-275. [CrossRef]

13. Ibáñez, S.J.; Feu, S.; Cañadas, M.; Gónzález-Espinosa, S.; García-Rubio, J. Estudio de los Indicadores de Rendimiento de Apendizaje Tras la Implementación de un Programa de Intervención Tradicional y Alternativo para la Enseñanza del Baloncesto. Kronos 2016, 15, 1-12.

14. González-Espinosa, S.; Antúnez, A.; Feu, S.; Ibáñez, S.J. Monitoring the External and Internal Load Under 2 Teaching Methodologies. J. Strength Cond. Res. 2018. [CrossRef] [PubMed]

15. García-Ceberino, J.M.; Antúnez, A.; Feu, S.; Ibáñez, S.J. Quantification of Internal and External Load in School Football According to Gender and Teaching Methodology. Int. J. Environ. Res. Public Health 2020, 17, 344. [CrossRef] [PubMed]

16. Yáñez, J.; Castejón, F.J. La utilización de la transferencia para el aprendizaje de la táctica colectiva deportiva en Educación Secundaria. Infanc. Aprendiz. 2011, 34, 95-107. [CrossRef]

17. Light, R.L.; Harvey, S. Positive Pedagogy for sport coaching. Sport Educ. Soc. 2017, 22, 271-287. [CrossRef]

18. González-Víllora, S.; García-López, L.M.; Gutiérrez-Díaz, D.; Pastor-Vicedo, J.C. Tactical awareness, decision making and skill in youth soccer players (under-14 years). J. Hum. Sport Exerc. 2013, 8, 412-426. [CrossRef]

19. Alarcón, F.; Cárdenas, D.; Miranda, M.T.; Ureña, N.; Piñar, M.I. Influencia del programa de entrenamiento reflexivo sobre el conocimiento declarativo de un equipo de baloncesto. Cuad. Psicol. Deporte 2011, 11, 19-28.

20. Starkes, J.L.; Ericsson, K.A. Expert Performance in Sports: Advances in Research on Sport Expertise; Human Kinetics: Champaign, IL, USA, 2003.

21. Moreno, A.; Moreno, P.; García-González, L.; Gil, A.; Del Villar, F. Desarrollo y validación de un cuestionario para la evaluación del conocimiento declarativo en voleibol. Mot. Eur. J. Hum. Mov. 2010, 25, 183-195.

22. Fernández-Echeverría, C.; Moreno-Arroyo, A.; Gil-Arias, A.; Claver-Rabaz, F.; Moreno-Arroyo, P. Estudio del conocimiento procedimental, experiencia y rendimiento, en jóvenes jugadores de voleibol. Retos Nuevas Tend. Educ. Física Deporte Recreación 2014, 25, 13-16.

23. Serra-Olivares, J.; García-López, L.M.; Calderón, A. Conocimiento específico de dominio táctico en futbolistas de 8 a 12 años. Apunt. Educ. Física Deportes 2015, 122, 36-43. [CrossRef] 
24. Serra-Olivares, J.; García-López, L.M.; Calderón, A.; Cuevas-Campos, R. Relación del conocimiento táctico de jóvenes futbolistas con la edad, la experiencia y el nivel de pericia. Cuad. Psicol. Deporte 2015, 15, 105-112. [CrossRef]

25. Williams, A.M.; Davids, K. Declarative knowledge in sport: A by-product of experience or a characteristic of expertise? J. Sport Exerc. Psychol. 1995, 17, 259-275. [CrossRef]

26. García, L.; Moreno, M.P.; Moreno, A.; Iglesias, D.; Del Villar, F. Análisis de las diferencias en el conocimiento de los jugadores de tenis, en función del nivel de pericia deportiva. Mot. Eur. J. Hum. Mov. 2008, 21, 31-53.

27. Giacomini, D.S.; Soares, V.O.; Santos, H.F.; Matias, C.J.; Greco, P.J. O conhecimento tático declarativo e processualem jogadores de futebol de diferentes escalões. Motricidade 2011, 7, 43-53. [CrossRef]

28. Kannekens, R.; Elferink-Gemser, M.T.; Post, W.J.; Visscher, C. Self-assessed tactical skills in elite youth soccer players: A longitudinal study. Percept. Mot. Ski. 2009, 109, 459-472. [CrossRef]

29. Kannekens, R.; Elferink-Gemser, M.T.; Visscher, C. Tactical skills of world-class youth soccer teams. J. Sports Sci. 2009, 27, 807-812. [CrossRef]

30. Koivula, N. Perceived characteristics of sports categorized as gender-neutral, feminine and masculine. J. Sport Behav. 2001, 24, 377-393.

31. With-Nielsen, N.; Pfister, G. Gender constructions and negotiations in physical education: Case studies. Sport Educ. Soc. 2011, 16, 645-664. [CrossRef]

32. Moreno, J.A.; Martínez, C.; Villodre, N.A. Actitudes hacia la práctica físico-deportiva según el sexo del practicante. Rev. Int. Cienc. Deporte 2006, 2, 20-43. [CrossRef]

33. Ruiz, L.M.; Graupera, J.L.; Mata, E. Preferencias participativas en Educación Física de los chicos y chicas de educación secundaria mediante la "escala GR de participación social en el aprendizaje". Mot. Eur. J. Hum. Mov. 2004, 12, 151-168.

34. Serra-Olivares, J. Conocimiento sobre la táctica deportiva de alumnos de educación primaria (Sport tactical knowledge of primary school students). Sport-TK Rev. Euroam. Cienc. Deporte 2014, 3, 11-20. [CrossRef]

35. Buscá, B.; Riera, J.; Sevilla, L.G. Design of a new test to assess cognitive skills in sport. Reliability and validity study. Rev. Psicol. Deporte 2010, 19, 277-290.

36. Griffin, L.L.; Dodds, P.; Placek, J.H.; Tremino, F. Middle school students' conceptions of soccer: Their solutions to tactical problems. J. Teach. Phys. Educ. 2001, 20, 324-340. [CrossRef]

37. González-Víllora, S.; García-López, L.M.; Gutiérrez-Díaz, D.; Contreras-Jordán, O.R. Tactical awareness and decision making in youth football players (12 years): A descriptive study. Infanc. Aprendiz. 2010, 33, 489-501. [CrossRef]

38. González-Víllora, S. Estudio de las etapas de formación del joven deportista desde el desarrollo de la capacidad táctica. In Aplicación al Fútbol; Proquest: Cambridge, UK, 2010.

39. Serra-Olivares, J.; García-López, L.M. Diseño y validación del test de conocimiento táctico ofensivo en fútbol (TCTOF)/Design and Validation of the Soccer Tactical Knowledge Test (STKT). Rev. Int. Med. Cienc. Act. Física Deporte 2016, 16, 521-536. [CrossRef]

40. Ato, M.; López, J.J.; Benavente, A. Un sistema de clasificación de los diseños de investigación en psicología. An. Psicol. 2013, 29, 1038-1059. [CrossRef]

41. García-Ceberino, J.M.; Feu, S.; Ibáñez, S.J. Comparative Study of Two Intervention Programmes for Teaching Soccer to School-Age Students. Sports 2019, 7, 74. [CrossRef]

42. García-Ceberino, J.M.; Antúnez, A.; Feu, S.; Ibánez, S.J. Validación de dos programas de intervención para la enseñanza del fútbol escolar / Validation of Two Intervention Programs for Teaching School Soccer. Rev. Int. Med. Cienc. Act. Física Deporte 2020, in press.

43. Bayer, C. La Enseñanza de los Juegos Deportivos Colectivos; Hispano Europea: Barcelona, Spain, 1992.

44. Cabero, J.; Barroso, J. La utilización del juicio de experto para la evaluación de TIC: El coeficiente de competencia experta. Bordón 2013, 65, 25-38. [CrossRef]

45. Field, A. Discovering Statistics Using SPSS; Sage publications: London, UK, 2009.

46. Cohen, J. Statistical Power Analysis for the Behavioral Sciences, 2nd ed.; Erlbaum: Hillsdale, NJ, USA, 1988.

47. Lenhard, W.; Lenhard, A. Calculation of Effect Sizes; Psychometrica: Bibergau, Germany, 2016. [CrossRef]

48. Pawlowki, C.S.; Ergler, C.; Tjornhoj-Thomsen, T.; Schipperijn, J.; Troelsen, J. "Like a soccer camp for boys": A qualitative exploration of gendered activity patterns in children's self-organized play during school recess. Eur. Phys. Educ. Rev. 2015, 21, 275-291. [CrossRef] 
49. Nielsen, G.; Pfister, G.; Andersen, L.B. Gender differences in the daily physical activities of Danish school children. Eur. Phys. Educ. Rev. 2011, 17, 69-90. [CrossRef]

50. Otero, F.M. Análisis de los elementos determinantes en la aplicación de una tarea evaluativa en educación física: Propuesta para un deporte de cooperación-oposición y participación simultánea. Tándem Didáctica Educ. Física 2005, 18, 59-69.

51. Otero, F.M.; Calvo, A.; González, J.A. Análisis de la Evaluación de los Deportes de Invasión en Primaria. Cult. Cienc. Deporte 2014, 9, 139-153. [CrossRef]

52. Hernández, J. La iniciación a los deportes desde su estructura y dinámica. In Aplicación a la Educación Física Escolar y al Entrenamiento Deportivo; Inde: Barcelona, Spain, 2000.

53. Stolz, S.; Pill, S. Teaching games and sport for understanding: Exploring and reconsidering its relevance in physical education. Eur. Phys. Educ. Rev. 2014, 20, 36-71. [CrossRef]

54. Persky, A.M.; Robinson, J.D. Moving from Novice to Expertise and Its Implications for Instruction. Am. J. Pharm. Educ. 2017, 81, 6065. [CrossRef]

55. González-Víllora, S.; García-López, L.M.; Contreras-Jordán, O.R. Evolución de la toma de decisiones y la habilidad técnica en fútbol/Decision making and skill development in youth football players. Rev. Int. Med. Cienc. Act. Fis. Deporte 2015, 15, 467-487. [CrossRef]

56. Harvey, S.; Song, Y.; Baek, J.-H.; van der Mars, H. Two sides of the same coin: Student physical activity levels during a game-centred soccer unit. Eur. Phys. Educ. Rev. 2016, 22, 411-429. [CrossRef]

57. Slingerland, M.; Haerens, L.; Cardon, G.; Borghouts, L. Differences in perceived competence and physical activity levels during single-gender modified basketball game play in middle school physical education. Eur. Phys. Educ. Rev. 2014, 20, 20-35. [CrossRef]

58. Figueiredo, L.M.; Lago, C.; Fernández-Villarino, M. Análisis del efecto de un modelo de evaluación recíproca sobre el aprendizaje de los deportes de equipo en el contexto escolar. Mot. Eur. J. Hum. Mov. 2008, 21, 102-122.

59. Memmert, D.; Harvey, S. Identification of non-specific tactical tasks in invasion games. Phys. Educ. Sport Pedagog. 2010, 15, 287-305. [CrossRef]

(C) 2020 by the authors. Licensee MDPI, Basel, Switzerland. This article is an open access article distributed under the terms and conditions of the Creative Commons Attribution (CC BY) license (http://creativecommons.org/licenses/by/4.0/). 